\title{
MIR92A1 wt Allele
}

National Cancer Institute

\section{Source}

National Cancer Institute. MIR92A1 wt Allele. NCI Thesaurus. Code C81944.

The human MIR92A1 wild-type allele is located in the vicinity of $13 q 31.3$ and is approximately $77 \mathrm{~b}$ in length. This allele, which encodes MIR92A1 pre-miRNA, plays a role in the regulation of gene expression. Alteration in the expression of this gene is associated with the development of hepatocellular carcinoma and medulloblastoma. 